\title{
Studi Banding Spam-Assassin Mail Server Dengan dan Tanpa Filter di Sisi Mail Client
}

\author{
Nurlina $^{* 1}$, Irmayana ${ }^{2}$ \\ ${ }^{1}$ Sistem Informasi STMIK DIPANEGARA Makassar \\ ${ }^{2}$ Teknik Informatika STMIK DIPANEGARA Makassar \\ E-mail: *1linanoer888@yahoo.com, ${ }^{2 i r m a y a n a @ y a h o o . c o m ~}$
}

\begin{abstract}
Abstrak
Filter spam yang disediakan oleh situs penyedia layanan email seperti yahoo, gmail, aim mail, windows live hotmail, dan masih banyak lagi yang lainnya, merupakan fasilitas yang sangat bermanfaat bagi para usernya. Filter spam tidak akan berfungsi sebagaimana yang diharapkan oleh user client. Pada saat alamat email para client sudah pernah di subscribe dengan tujuan tertentu seperti misalnya untuk registrasi mailing list, newsgroup, dan lain sebagainya, maka alamat emailnya itu sudah tidak aman lagi dari para spammer. Pada dasarnya para admin mail server hanya menggunakan secara langsung filter spam yang disediakan oleh mail server yang diinstal, tanpa memberikan penyettingan tertentu yang dibutuhkan client sama sekali. Para user sendiri yang seharusnya lebih aktif dalam menyaring spam pada email yang digunakan dengan banyak cara. Penelitian ini memanfaatkan aplikasi mail client Thunderbird untuk menyaring spam dengan metode Bayesian sebagai kelanjutan dari menyaring spam yang sudah tersaring sebelumnya pada sisi mail server dan bertujuan menganalisis hasil pengklasifikasian email ham dan email spam pada mail server dan mail client. Disimpulkan bahwa nilai akurasi dan error filter spam pada mail server berhubungan dengan filter Spam-Assassin yang tidak disetting dan dikonfigurasi oleh adminnya menunjukkan hasil yang tidak memuaskan dibandingkan dengan filter spam metode bayesian pada mail client yang sudah di-training.
\end{abstract}

Kata Kunci - Studi Banding, Spam Assassin, Mail Server, Metode Bayesian, Mail Client

\begin{abstract}
Spam filters provided by your email service provider websites such as yahoo, gmail, AIM mail, windows live hotmail, and many others, is a very powerful feature for the user. The spam filter will not work as expected by the client user. at the time of the email address of the client has been ever subscribe to a specific purpose such as for registration, mailing lists, newsgroups, and so forth, then the email address is no longer safe from spammers. Basically the admin mail server directly using only the spam filter provided by the mail server is installed, without giving a specific setting it takes the client at all. The users themselves are supposed to be more active in the spam filter on the email that is used in many ways. This study utilizes Thunderbird mail client application to filter spam with Bayesian methods as a continuation of the spam filter that has been previously filtered on the mail server and to analyze the results of the classification of ham and spam e-mail on the mail server and mail client. It was concluded that the accuracy and error spam filter on the mail server associated with the filter SpamAssassin is not be set and configured by the admin showed unsatisfactory results compared with the Bayesian method to filter spam mail client that is already in-training
\end{abstract}

Keywords - Comparative Study, Spam-Assassin, Mail Server, Metode Bayesian, Mail Client 


\section{PENDAHULUAN}

Penelitian ini dilakukan awalnya karena peneliti selalu mendapatkan email spam setiap hari pada emailnya dengan domain yahoo.com. Seperti kita ketahui, domain yahoo.com sudah menyediakan folder khusus untuk email spam, namun kenyataannya tidak semua email spam langsung masuk pada folder yang sudah disediakan. Sedangkan email yang seharusnya masuk di inbox penerima justru masuk pada folder spam sehingga email yang penting terkadang tidak dibaca oleh yang bersangkutan. Peneliti menyelidiki email dengan domain yahoo.com menyediakan folder spam yang memanfaatkan anti spam yang bernama program SpamAssassin. Anti spam ini merupakan program yang terintegrasi dari software mail server yang digunakan. Jadi secara otomatis penggunaannya juga merupakan default dari yang sudah disediakan oleh mail server. Spam-Assassin memiliki berbagai macam aturan menyangkut spam. Berangkat dari hal tersebut, peneliti mencoba mengangkat permasalahan ini yang menurut hematnya belum ada yang menyelidiki tentang aturan-aturan dari yang disediakan Spam-Assassin tersebut.

\section{METODE PENELITIAN}

Studi banding ini menggunakan dua metode yaitu metode Spam-Assassin dan metode Bayesian. Untuk mendapatkan data di lapangan digunakan teknik observasi dan wawancara. Menghimpun bahan-bahan keterangan yang dilakukan dengan mengadakan pengamatan dan pencatatan secara sistematis terhadap fenomena-fenomena yang dijadikan objek pengamatan dan dengan menghimpun bahan-bahan keterangan dengan tanya jawab secara lisan, sepihak, berhadapan muka dengan arah tujuan yang telah ditentukan.

Populasi dalam penelitian ini adalah keseluruhan email spam dan email ham yang masuk dalam inbox account linanoer888@unhas.ac.id yang jumlahnya dapat dilihat pada Tabel 1. Email spam juga berasal dari account linanoer888@yahoo.com, yang terakumulasi pada Tabel 2. Email ham yang berasal juga dari linanoer@unhas.ac.id seperti pada Tabel 3. Emailemail yang tersimpan dalam mailbox / maildir server Universitas Hasanuddin.

Tabel 1. Populasi account linanoer888@unhas.ac.id

\begin{tabular}{ccc}
\hline $\begin{array}{c}\text { Total } \\
\text { Emails }\end{array}$ & $\begin{array}{c}\text { Email } \\
\text { Ham }\end{array}$ & $\begin{array}{c}\text { Email } \\
\text { Spam }\end{array}$ \\
\hline 722 & 210 & 512 \\
\hline $100 \%$ & $29,09 \%$ & $70,91 \%$ \\
\hline
\end{tabular}

Tabel 2. Populasi account linanoer888@yahoo.com

\begin{tabular}{ccc}
\hline $\begin{array}{c}\text { Total } \\
\text { Emails }\end{array}$ & $\begin{array}{c}\text { Email } \\
\text { Ham }\end{array}$ & $\begin{array}{c}\text { Email } \\
\text { Spam }\end{array}$ \\
\hline 274 & 18 & 256 \\
\hline $100 \%$ & $6,57 \%$ & $93,43 \%$ \\
\hline
\end{tabular}

Tabel 3. Populasi account linanoer@unhas.ac.id

\begin{tabular}{ccc}
\hline $\begin{array}{c}\text { Total } \\
\text { Emails }\end{array}$ & $\begin{array}{c}\text { Email } \\
\text { Ham }\end{array}$ & $\begin{array}{c}\text { Email } \\
\text { Spam }\end{array}$ \\
\hline 10 & 10 & 0 \\
\hline $100 \%$ & $100 \%$ & $0 \%$ \\
\hline
\end{tabular}


Spesifikasi hardware untuk mail server sangat tergantung pada tingkat kebutuhan dan software yang digunakan. Kebutuhan hardware minimum untuk Apache sebagai mail server adalah komputer Intel @ Xeon CPU E540 @ 2.00 GB dengan RAM 1 GB dan HDD 250 GB. Struktur mail server yang digunakan di Universitas Hasanuddin seperti terlihat pada gambar 1, yang terdiri dari komponen-komponen: Apache sebagai Web Server, Linux Debian sebagai Sistem Operasi, Postfix sebagai MTA, Vmail untuk fungsi support Multi Domain pada MTA, Postfix-maildrop sebagai MDA untuk melakukan email scanning dan mengintegrasikan ClamAv serta Spam Assassin, Database MySQL, Amavisd-New sebagai Content-Checks antara ClamAv dan Spam Assassin, Spam-Assassin 3.2.5 sebagai Anti Spam, ClamAV sebagai Anti Virus, SASL + TLS/SSL sebagai Secure Authentication dan Encryption, belum memiliki fitur mailing_list, Courier IMAPS/POP3S/Devecot sebagai IMAP Server(IMAPS)/POP3S untuk menyediakan akses webmail melalui IMAPS (port 993)/POP3S (port 995), dan RoundCube sebagai MUA berbasis Webmail.

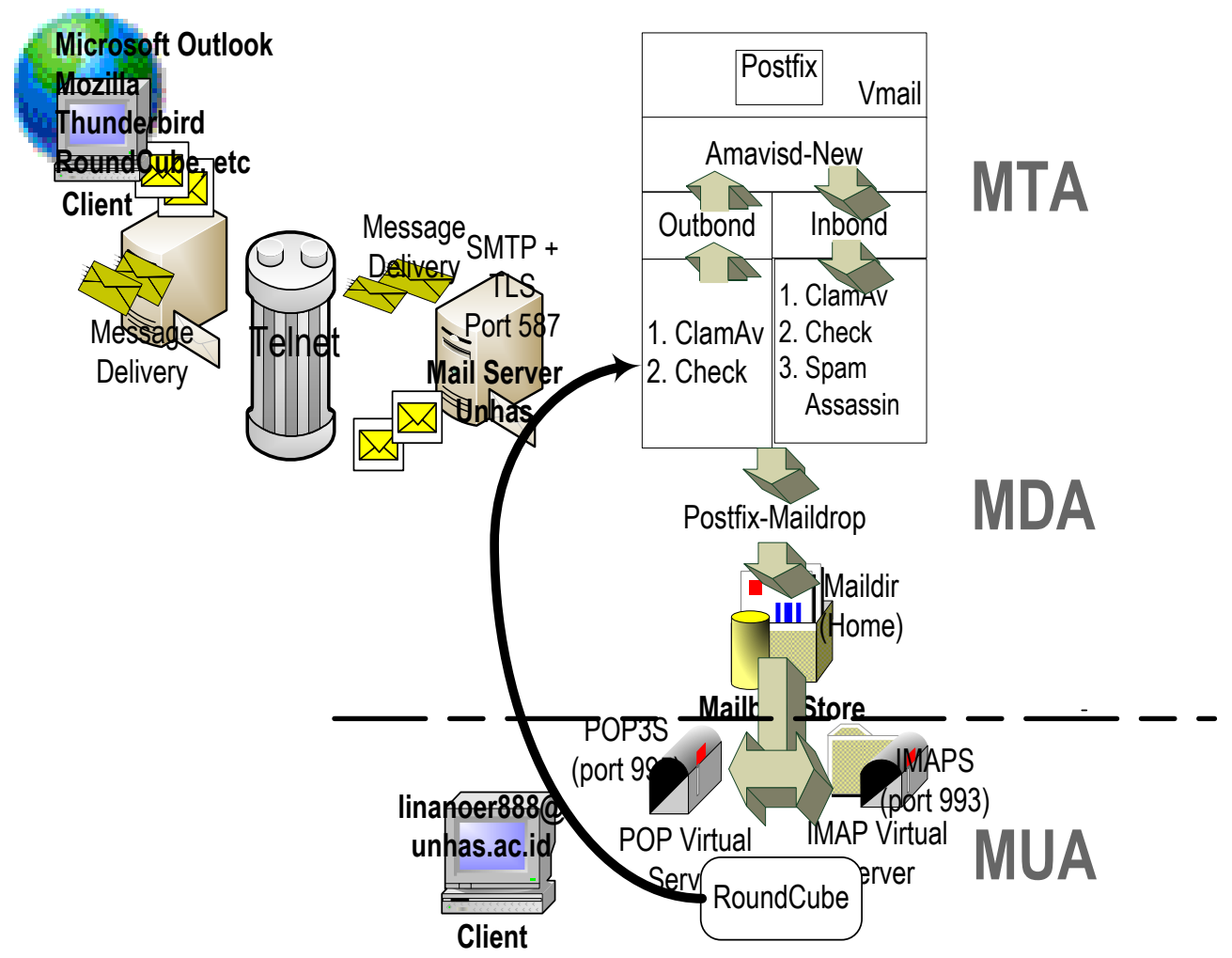

Gambar 1. Struktur Mail Server Universitas Hasanuddin

(Sumber: Pratama, 2008)

Dari gambar 3, tampak pemisahan sisi server (MTA \& MDA) dari sisi client (MUA). Pada gambar tersebut juga ditunjukkan bagaimana hubungan interaksi antara MTA, MDA, dan MUA, serta keterlibatan komponen-komponen yang mendukung, baik yang berada di sisi MTA (ClamAV dan Spam-Assassin), di sisi MDA (Postfix_Maildrop), dan di sisi MUA (RoundCube). Pengiriman E-Mail ke internet dilakukan melalui SMTP Relay pada server SMTP milik ISP Telnet. Protokol SMTP berfungsi untuk mendownload pesan dari klien E-Mail ke server SMTP yang ada di ISP. Selanjutnya server SMTP melakukan pengiriman E-Mail ke alamat tujuan masing-masing. Karena tugas sebagai mediator tersebut maka server SMTP di ISP disebut sebagai SMTP relay. Server SMTP dari ISP Telnet mengijinkan untuk menerima relay E-Mail dari domain unhas.ac.id. Admin melakukan authentifikasi dengan user name dan password tiap user sebelum mengirim melalui server SMTP ISP Telnet. Hal ini dilakukan untuk mencegah tindakan spam yang sangat merugikan ISP maupun penerima E-Mail [6]. 
Pengambilan E-Mail di Unhas dilakukan dengan metode MultiPOP yakni menggunakan protokol POP3S/IMAPS untuk mendownload E-Mail dari server POP3S/IMAPS ke mail server jaringan. Sebelum mengambil E-Mail harus diberikan informasi mengenai account user serta password sehingga server POP3S/IMAPS dapat mengenali identitas mailbox yang akan didownload. E-Mail tiap user di simpan di mailboxnya masing-masing, tidak digabungkan dalam satu mailbox. Tiap account memiliki alamat dan password masing-masing sehingga harus dilakukan konfigurasi MultiPOP untuk tiap user di mail server. Mail Server berjalan dengan beberapa protokol pada TCP/IP, yakni SMTP dan TLS (port 587), POP3S (port 995), dan IMAPS (port 993). Mail Server memiliki tiga komponen utama yang menyusunnya, yakni Mail Transfer Agent (MTA), Mail Delivery Agent (MDA), dan Mail User Agent (MUA). MTA bertugas mengatur pengiriman dan penerimaan e-mail, MDA bertugas mengatur pengiriman email ke alamat yang sesuai pada jaringan lokal, sementara MUA bertugas untuk menjadi antarmuka yang menghubungkan user dengan Mail Server [6].

Studi banding (comparison study) biasa dilakukan untuk maksud peningkatan mutu, perluasan usaha, perbaikan sistem, penentuan kebijakan baru, perbaikan peraturan perundangan, dan lain-lan. Kegiatan studi banding dilakukan oleh kelompok kepentingan untuk mengunjungi atau menemui obyek tertentu yang sudah disiapkan dan berlangsung dalam waktu relatif singkat. Intinya adalah untuk membandingkan kondisi obyek studi di tempat lain dengan kondisi yang ada di tempat sendiri. Hasilnya berupa kumpulan data dan informasi sebagai bahan acuan dalam perumusan konsep yang diinginkan[1].

Spam-Assassin adalah aplikasi yang sudah teruji secara luas menggunakan proyek open source yang berfungsi sebagai mail filter untuk mengidentifikasikan spam. Spam-Assassin berjalan pada server, dan sebagai filter spam sebelum mencapai kotak surat user. SpamAssasin menyaring e-mail masuk sehingga $e$-mail account milik pelanggan web hosting terlindungi dari SPAM. Spam-Assassin diintegrasikan ke dalam mail server untuk secara otomatis menyaring semua spam untuk domain dan aturan penggunaan, atau "tes," untuk menentukan apa yang spam dan apa yang tidak. SpamAssasin dapat memberikan tanda dengan mengubah subject $e$ mail atau langsung menghapus e-mail SPAM yang masuk. Setiap user dapat mengkonfigurasi ambang batas Spam-Assassin untuk menentukan jika sebuah email adalah spam, dicurigai spam, atau bukan spam. Spam-Assassin dirancang untuk memberikan penyaringan yang dapat diterima tanpa pelatihan apapun dan tentu saja bisa diperbaiki jika tiap user menghabiskan waktu untuk melatihnya [7].

Spam-Assassin menggunakan berbagai mekanisme berikut [7] :

1. Pengecekan Header Email

2. Pengecekan isi email

3. Pengelompokan Email Address secara otomatis/manual menjadi Whitelist ataupun Blacklist

4. Bayesian Filtering

5. Penyaringan database spam kolaboratif (DCC, Pyzor, Razor2)

6. Berbasis jaringan seperti Blacklist URL, Blacklist DNS, Checksum berbasis Filter, dan Algoritma Hash

Mail Server merupakan server yang melayani beberapa komputer dalam suatu jaringan internet, ekstranet dan intranet dalam bentuk layanan pengiriman dan pengambilan e-mail. Mesin ini senantiasa menerima pesan dari email client yang digunakan user atau mugkin dari email server yang lainnya. Sebuah mail server biasanya terdiri dari area penyimpanan, set konfigurasi user, daftar user dan seri modul komunikasi [2]. Mail Server adalah suatu entitas berupa komputer yang bertindak sebagai sebuah server (penyedia layanan) dalam jaringan komputer / internet, serta memiliki fungsi untuk melakukan penyimpanan (storing) dan distribusi yang berupa pengiriman (sending), penjaluran (routing), dan penerimaan (receiving) e-mail. Mail Server berjalan dengan beberapa protokol pada TCP/IP, yakni SMTP (port 25), POP3 (port 110), dan IMAP (port 143). Mail Server memiliki tiga komponen utama yang menyusunnya, yakni Mail Transfer Agent (MTA), Mail Delivery Agent (MDA), dan Mail User Agent (MUA). MTA bertugas mengatur pengiriman dan penerimaan e-mail, MDA bertugas 
mengatur pengiriman e-mail ke alamat yang sesuai pada jaringan lokal, sementara MUA bertugas untuk menjadi antarmuka yang menghubungkan user dengan Mail Server [5].

\section{a. Storage Area}

Adalah tempat pesan email disimpan untuk user dan sebagai transit sebelum menuju tujuan lainnya.

\section{b. Set konfigurasi user}

Adalah untuk user yang menetapkan bagaimana mail server harus beraksi saat menerima pesan tertentu atau mungkin mengambil keputusan untuk pengirim tertentu. Sebagai contoh, address tertentu mungkin dibatasi untuk hanya dapat mengirim pesan dalam lingkungan perusahaan saja.

c. Daftar/list user

Adalah database account user yang dikenali mail server dan akan berkomunikasi dengan mereka secara lokal.

d. Modul komunikasi

Adalah komponen yang aktualnya menangani transfer pesan ke dan dari mail server lain dan atau klien lain. Modul yang terinstal dalam mail server ini dapat berbeda-beda sesuai kebutuhan.

Mail server hanya sebuah aplikasi yang berurusan dengan lalu lintas email. Tidak secara langsung berhubungan dengan user yang akan berkirim email. Dalam pengiriman email, terdapat dua aplikasi yang diperlukan yaitu MTA (Mail Transfer Agent), dan MUA (Mail User Agent).

Secara garis besar MTA adalah aplikasi server yang berfungsi untuk mengirimkan $e$ mail dari mail server local ke mail server remote. Salah satu contoh jenis MTA yang terkenal dan digunakan dalam proyek akhir ini adalah postfix [2].

Berikut beberapa fungsi dari MTA:

1. Pertukaran email menggunakan protocol TCP.

2. Menerima email masuk (incoming).

3. Meneruskan email yang akan keluar (outgoing).

Sedangkan MUA adalah aplikasi yang berfungsi sebagai interface antara email, dalam hal ini berhubungan dengan user yang memiliki email tersebut, dengan MTA yang mendukungnya. Berfungsi sebagai berikut:

1. Menulis email dan membaca email yang masuk [2].

2. Mengatur konfigurasi email sehingga sesuai dengan MTA yang mendukungnya.

Secara ringkas, cara kerja Mail Server ditunjukkan dalam gambar 2 dan gambar 3 [5].

Email client, email pembaca, atau lebih formal disebut mail user agent (MUA), adalah sebuah program komputer yang digunakan untuk mengelola email. Secara khusus, istilah email client dapat merujuk kepada setiap agen yang bertindak sebagai client ke mail server, terlepas dari itu menjadi pengguna email agen, menyampaikan ke server, atau diketikkan manusia pada sebuah terminal. Selain itu, sebuah aplikasi web menyediakan pengelolaan pesan, komposisi, dan fungsi penerimaan yang kadangkadang dianggap sebagai email client.

Seperti kebanyakan program client, sebuah MUA hanya aktif ketika pengguna (user) menjalankannya. Pesan tiba di Mail Transfer Agent (MTA) server. Kecuali MUA yang memiliki akses ke penyimpanan server, pesan akan disimpan di sebuah server remote dan MUA harus mengambil mereka atas permintaan pengguna email. 


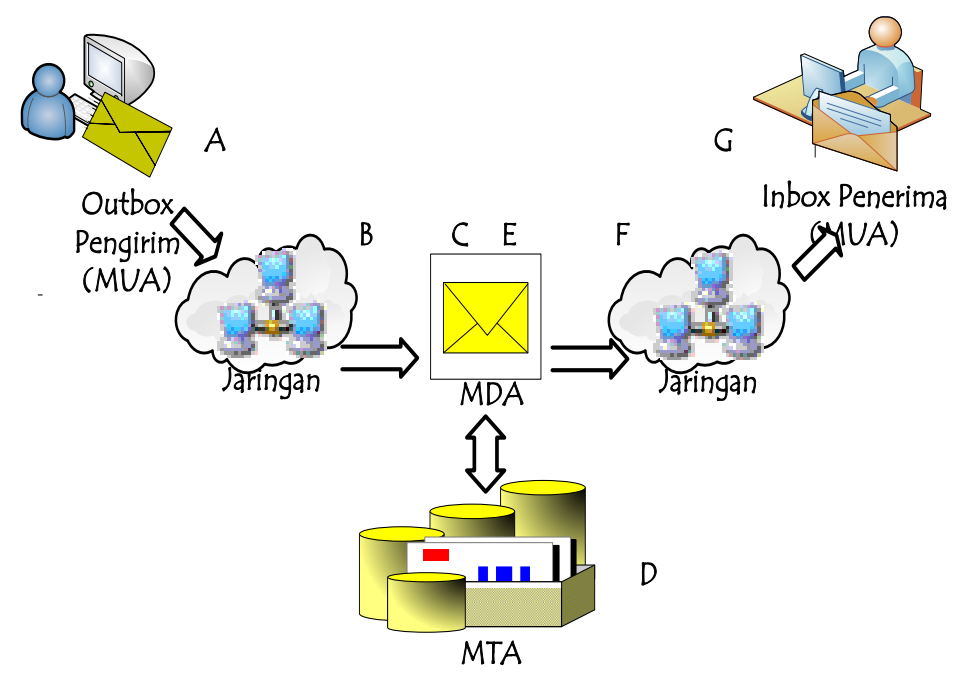

Gambar 2. Proses Pengiriman Email pada Jaringan Lokal

(Sumber: Pratama, 2008)
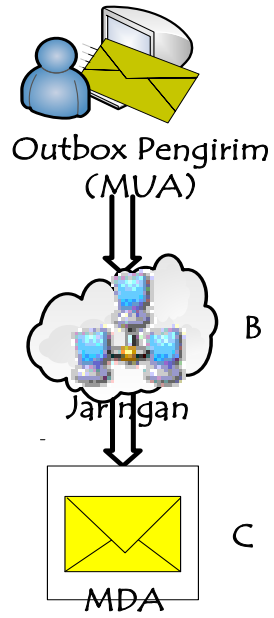

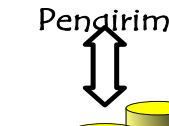

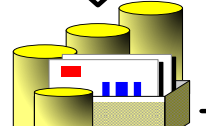

MTA Pengirim
A

A

1

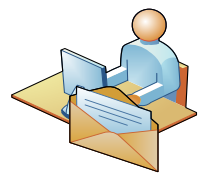

Inbox Penerima (MUA)

$\mathrm{H}$

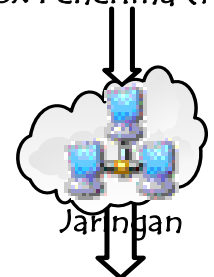

G

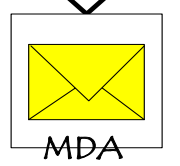

Gambar 3. Proses Pengiriman Email ke Jaringan Luar

(Sumber: Pratama, 2008)

Bayesian filter atau Naive Bayes Classifier merupakan metode terbaru yang digunakan untuk mengklasifikasikan sekumpulan dokumen. Algoritma ini memanfaatkan metode probabilitas dan statistik yang dikemukakan oleh ilmuwan Inggris Thomas Bayes, yaitu memprediksi probabilitas di masa depan berdasarkan pengalaman di masa sebelumnya. Dua kelompok peneliti, satu oleh Pantel dan Lin, dan yang lain oleh Microsoft Research memperkenalkan metode statistik Bayesian ini pada teknologi anti spam filter. Tetapi yang membuat algoritma Bayesian filtering ini popular adalah pendekatan yang dilakukan oleh Paul Graham [6]. 
Citec Journal, Vol. 1, No. 2, Februari 2014 - April 2014

Dasar dari teorema naive Bayes [6], yang digunakan dalam pemrograman adalah rumus Bayes berikut ini:

$$
\mathrm{P}(\mathrm{A} \mid \mathrm{B})=(\mathrm{P}(\mathrm{B} \mid \mathrm{A}) * \mathrm{P}(\mathrm{A})) / \mathrm{P}(\mathrm{B})
$$

Peluang kejadian A s ebagai B ditentukan dari peluang B saat A, pelu ang A, dan peluang B. Pada pengaplikasianny a nanti rumus ini berubah menjadi:

$$
\mathrm{P}(\mathrm{Ci} \mid \mathrm{D})=(\mathrm{P}(\mathrm{D} \mid \mathrm{C} \mathrm{i}) * \mathrm{P}(\mathrm{Ci})) / \mathrm{P}(\mathrm{D})
$$

Naive Bayes Classifier atau bisa disebut sebagai multinomial naive bayes merupakan model penyederhanaan dari algoritma bayes yang cocok dalam pengkl asifikasian text atau dokumen [8].

Persamaannya adalah:

$$
v_{M A P}=\underset{v_{j} \in v}{\arg \max } P\left(v_{j} \mid a_{1}, a_{2}, \ldots, a_{n}\right)
$$

Menurut persamaan (3), maka persamaan (1) dapat ditulis

$$
v_{M A P}=\underset{v_{j} \in v}{\arg \max } \frac{P\left(a_{1}, a_{2}, \ldots, a_{n} \mid v_{j}\right) P\left(v_{j}\right)}{P\left(a_{1}, a_{2}, \ldots, a_{n}\right)}
$$

$\mathrm{P}\left(\mathrm{a}_{1}, \mathrm{a}_{2}, . . \mathrm{a}_{\mathrm{n}}\right)$ konstan, sehingga dapat dihilangkan menjadi

$$
v_{M A P}=\underset{v_{j} \in v}{\arg \max } P\left(a_{1}, a_{2}, \ldots, a_{n} \mid v_{j}\right) P\left(v_{j}\right)
$$

Karena $P\left(a_{1}, a_{2}, . . a_{n} \mid v_{j}\right)$ sulit untuk dihitung, maka akan diasumsikan bahwa setiap kata pada dokumen tidak mempunyai keterkaitan.

$$
v_{M A P}=\underset{v_{j} \in v}{\arg \max } P\left(v_{j}\right) \prod_{i} P\left(a_{i} \mid v_{j}\right)
$$

Keterangan :

$$
\begin{gathered}
P\left(v_{j}\right)=\frac{\mid \text { docs }_{j} \mid}{\mid \text { Contoh } \mid \ldots . .} \\
P\left(w_{k} \mid v_{j}\right)=\frac{n_{k}+1}{n+\mid \text { kosakata } \mid} .
\end{gathered}
$$

Dimana untuk :

$\mathrm{P}\left(\mathrm{v}_{\mathrm{j}}\right) \quad$ : Probabilitas setiap dokumen terhadap sekumpulan dokumen.

$\mathrm{P}\left(\mathrm{w}_{\mathrm{k}} \mid \mathrm{v}_{\mathrm{j}}\right)$ : Probabilitas kemunculan kata $\mathrm{w}_{\mathrm{k}}$ pada suatu dokumen dengan kategori class $\mathrm{v}_{\mathrm{j}}$

| docs | : frekuensi dokumen pada setiap kategori

| Contoh | : jumlah dokumen yang ada

nk : frekuensi kata ke-k pada setiap kategori

kosakata : jumlah kata pada dokumen test 
Pada persamaan (8) terdapat suatu penambahan 1 pada pembilang, hal ini dilakukan untuk mengantisipasi jika terdapat suatu kata pada dokumen uji yang tidak ada pada setiap dokumen data training [1].

\section{HASIL DAN PEMBAHASAN}

Tabel 5 merupakan hasil analisa dan perhitungan data dengan mengamati secara umum data email ham yang dianggap spam disebut dengan false positive dan pengamatan data email spam yang lolos dari filter/anti spam yang disebut dengan false negative, langsung pada inbox mail client dengan account linanoer888@unhas.ac.id. Rasio antara email ham dan email spam tidak memberikan efek yang berarti pada filter, maksudnya bahwa rasio 1:1 juga tidak akan memberikan akurasi lebih baik dibanding rasio 5:1 [4].

Sedangkan pada sisi client, peneliti menggunakan aplikasi mail client Thunderbird pada notebook dengan sistem operasi Microsoft Windows XP Professional Versi 2002 Service Pack 2, Intel Atom $1.66 \mathrm{GHz}$ dan RAM 1 GB. Penggunaan daripada metode Bayesian Filter dalam penelitian ini dengan menginstalasi dan mengkonfigurasi software Thunderbird 1.0 atau Thunderbird 2.0. Thunderbird dipilih karena user friendly, freeware dan lintas platform. Pelatihan dan pengujian dilakukan sebanyak limabelas kali (15x) training dan total email yang digunakan dalam training sebanyak 996 email yang terdiri dari 233 email ham dan 768 email spam. Sedangkan data yang digunakan untuk mengujinya sebanyak 276 email spam dan 23 email ham. Tabel 6 merupakan hasil pengujian metode bayesian dengan menggunakan Thunderbird pada sisi client. Pengukuran kinerja dilihat dari false positive dan false negative atau accuracy dan error -nya.

Tabel 4. Hasil Analisa metode Spam-Assassin pada Mail Server Unhas

\begin{tabular}{ccccccc}
\hline $\begin{array}{c}\text { Total } \\
\text { Emails }\end{array}$ & $\begin{array}{c}\text { Email } \\
\text { Ham }\end{array}$ & $\begin{array}{c}\text { Email } \\
\text { Spam }\end{array}$ & $\begin{array}{c}\text { False } \\
\text { Pos. }\end{array}$ & $\begin{array}{c}\text { False } \\
\text { Neg. }\end{array}$ & Acc & Err \\
\hline 1006 & 238 & 768 & 18 & 511 & & \\
\hline $100 \%$ & $23.66 \%$ & $76.34 \%$ & $1.79 \%$ & $50.80 \%$ & $47.89 \%$ & $52.11 \%$ \\
\hline
\end{tabular}

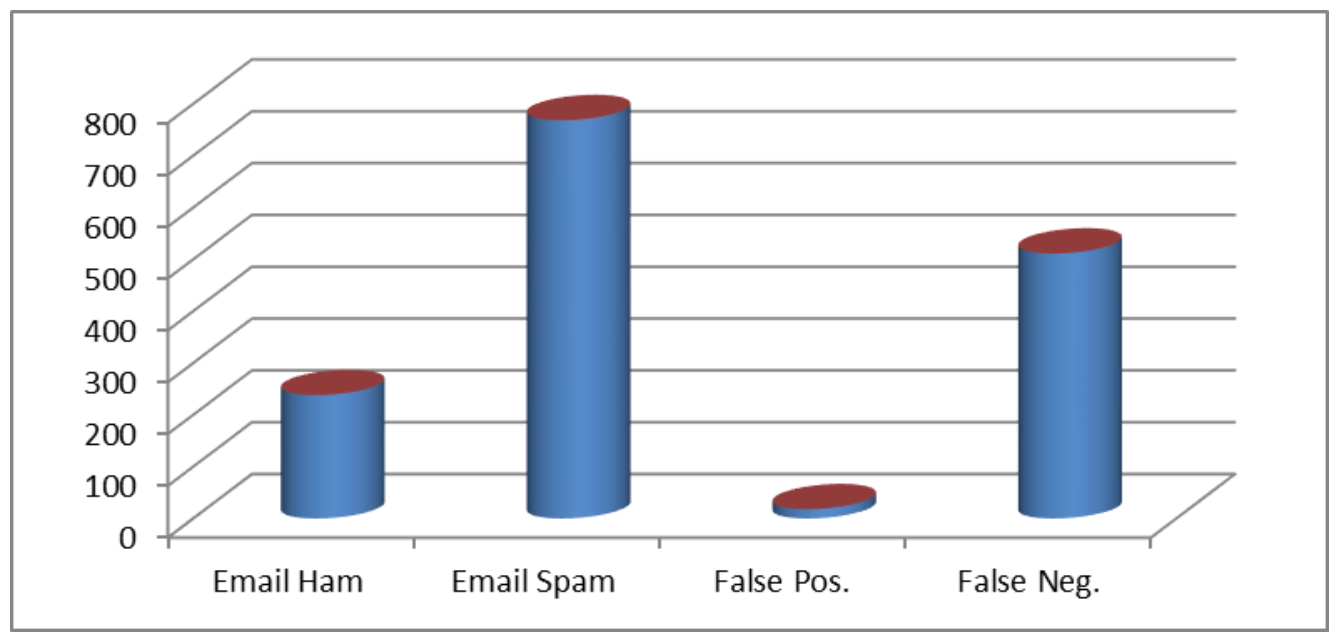

Gambar 4. Grafik Hasil Analisa Metode Spam-Assassin pada Mail Server Unhas 
Citec Journal, Vol. 1, No. 2, Februari 2014 - April 2014

Tabel 5. Hasil Pengujian Metode Bayesian pada Mail Client Thunderbird User

\begin{tabular}{ccccccc}
\hline $\begin{array}{c}\text { Total } \\
\text { Emails }\end{array}$ & $\begin{array}{c}\text { Email } \\
\text { Ham }\end{array}$ & $\begin{array}{c}\text { Email } \\
\text { Spam }\end{array}$ & $\begin{array}{c}\text { False } \\
\text { Pos. }\end{array}$ & $\begin{array}{c}\text { False } \\
\text { Neg. }\end{array}$ & Acc & Err \\
\hline 514 & 238 & 276 & 0 & 1 & & \\
\hline $100 \%$ & $46,30 \%$ & $53,70 \%$ & $0.00 \%$ & $0,2 \%$ & $99,98 \%$ & $0,02 \%$ \\
\hline & & & & & & \\
\hline \\
\hline
\end{tabular}

Gambar 5. Grafik Hasil Pengujian Metode Bayesian pada Mail Client Thunderbird User

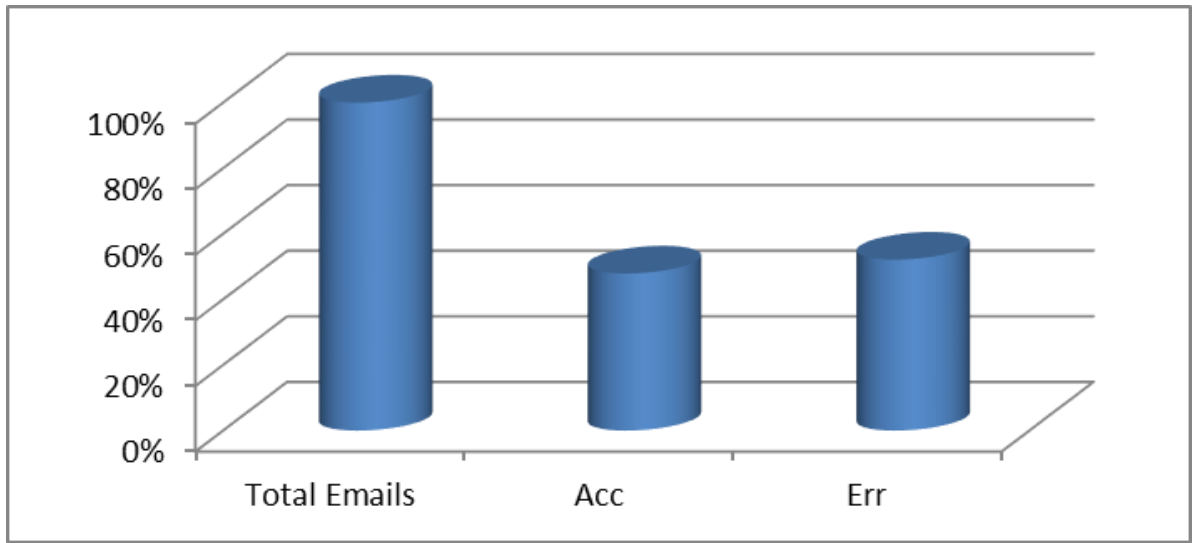

Gambar 6. Grafik Hasil Akurasi dan Error Metode Spam-Assassin pada Mail Server Unhas

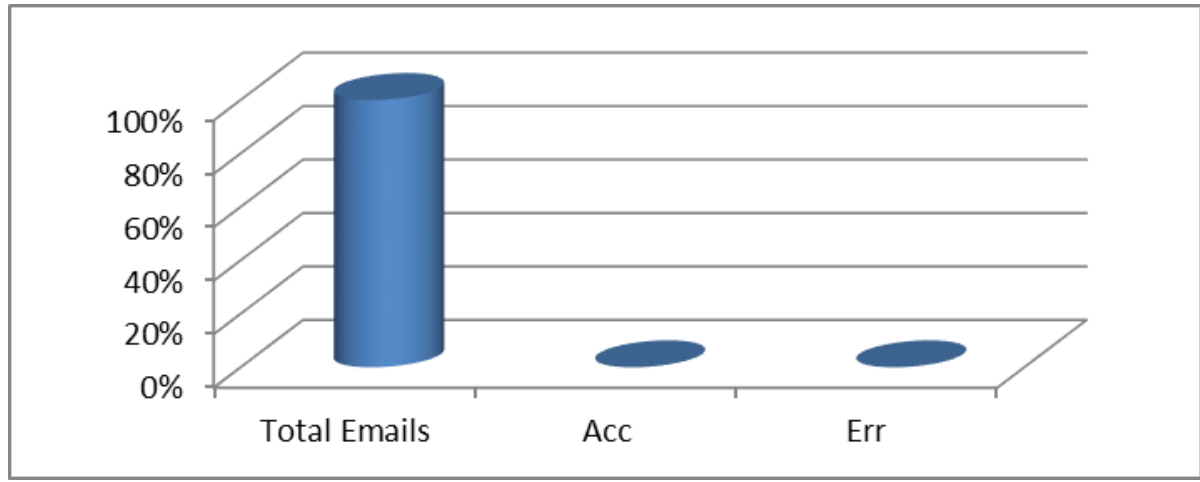

Gambar 7. Grafik Hasil Akurasi dan Error Metode Bayesian pada Mail Client Thunderbird

Berdasarkan pengamatan dari Tabel 4 dan Tabel 5 menunjukkan bahwa penggunaan metode Spam-Assassin pada Mail Server Unhas mencapai nilai akurasi 47,39\% dan nilai error 52,61\%. False Positive mencapai angka $1,31 \%$ yakni ada 13 email ham yang dianggap spam 
dan tidak masuk ke dalam inbox account peneliti. Hal ini sangat mengkhawatirkan karena email yang kita butuhkan informasinya menjadi tidak sampai dalam inbox kita. Beberapa hal yang menyebabkan demikian adalah berasal dari aturan Spam-Assassin 3.2.5 sendiri[8], yakni pengetesan Spam-Assassin 3.2.5 pada daerah 'header', SUBJ_ALL_CAPS, seluruh subject berisi huruf besar (huruf capital) dengan 1,926 point, FROM_ILLEGAL_CHARS, asal email (from dan subject) dituliskan dengan banyaknya karakter yang ilegal dengan 3,999 point dan 1,954 point, HEAD_LONG, terlalu panjangnya pesan yang dituliskan pada header nya dengan 2,5 points, pada daerah 'body', FUZZY_SOFTWARE, berisi kata-kata yang dianggap mengaburkan dalam spam) dengan 3,169 point dan UNWANTED_LANGUAGE_BODY, pesan ditulis dalam bahasa yang tidak diinginkan dengan 2,8 point. Standar dari Spam-Assassin agar email spam tidak masuk inbox ataupun tidak lolos dari filter adalah sebesar 5 point. Sedangkan False Negative mencapai nilai 51,31\% dengan 511 email spam yang lolos dari filter/anti spam Spam Assassin. Hanya satu email yang diberi tanda ***SPAM*** oleh Spam-Assassin seperti terlihat pada gambar 8 .

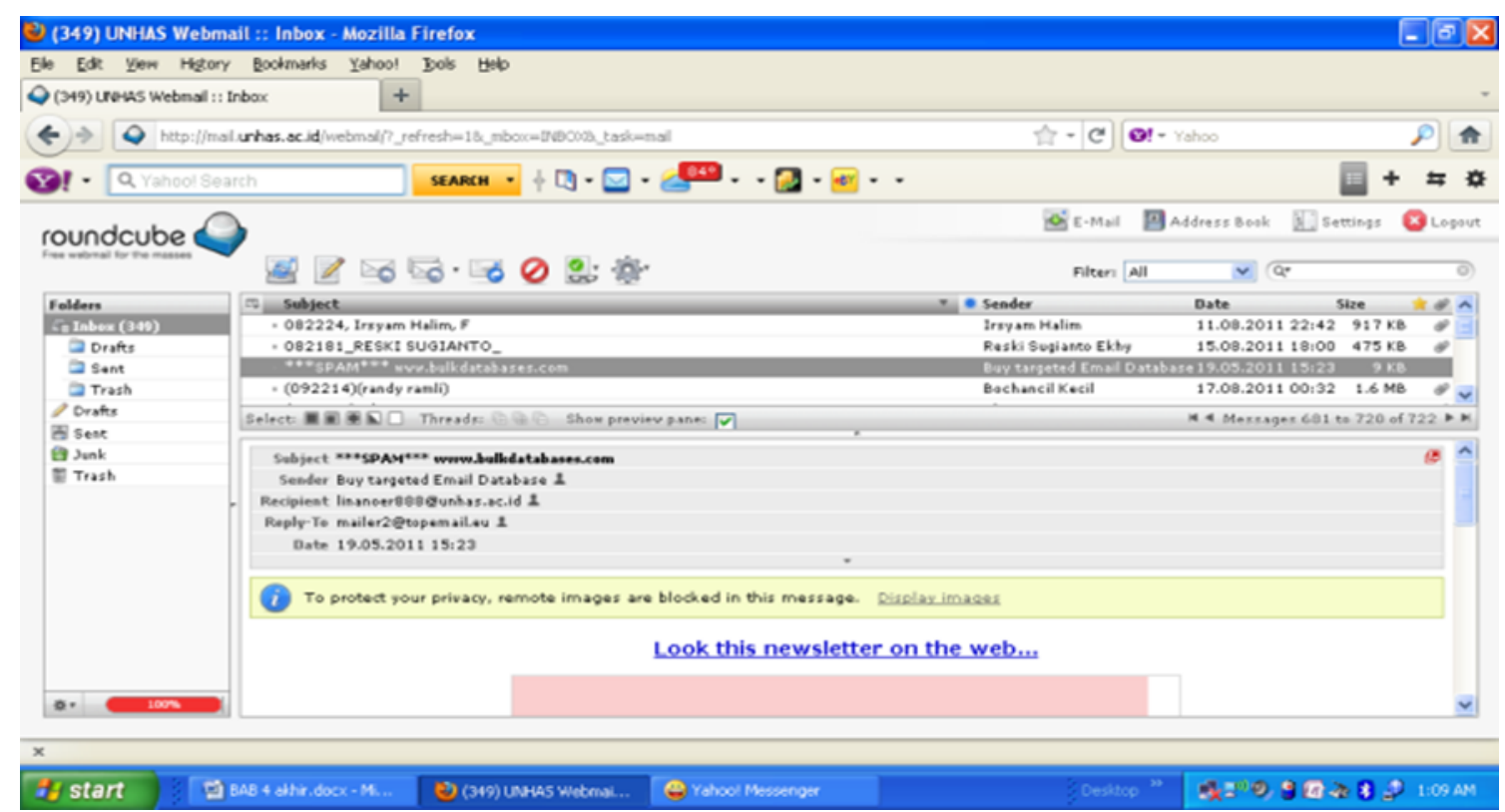

Gambar 8.Struktur Mail Server Universitas Hasanuddin

Mengapa email tersebut diberi tanda dan lolos dari filter sedangkan email yang sama sebelumnya lolos dan tanpa tanda ***SPAM***? Karena sebelumnya sudah banyak email seperti gambar 4 yang telah masuk dalam inbox user yang bersangkutan. Sehingga mendapat nilai score sesuai dengan aturan Spam-Assassin dengan nama tesnya masing-masing, DATE_IN_FUTURE_06_12, dengan 2,136 point, FH_MSGID_01C70XXX, nomor ID dari pesan tersebut sering kelihatan sebelumnya dalam jumlah banyak dengan 2,757 point dan TVD_SPACED_SUBJECT_WORD3, pada Subject terdapat kata FW/RE dengan 2,276 point.

Sebaiknya email dengan domain unhas.ac.id tersebut selanjutnya menggunakan pengujian metode Bayesian pada Mail Client sehingga bisa mencapai nilai akurasi sampai $99,98 \%$ dan nilai error hanya 0,02\%. Spam-Assassin yang sebenarnya memiliki metode bayesian yang terintegrasi di dalam mail server akan bermanfaat dan bisa berhasil menyaring sampai 99,98\% akuratnya bila di sisi server, adminnya langsung mentraining email user masing-masing, namun akan menyita waktu yang sangat lama bagi admin dan hal ini tidak akan mungkin dilakukan oleh siapa saja yang menjadi admin karena fasilitas metode bayesian yang disediakan harus juga senantiasa di update agar mendapatkan hasil yang maksimal. Seperti diketahui, spammer akan selalu meningkatkan cara dan pengetahuannya dalam menembus email dari korbannya. Maka dapat disimpulkan bahwa metode Bayesian akan sangat efektif dan cukup 
akurat dengan kinerja lebih baik apabila disepadankan dengan metode Spam-Assassin pada Mail Server khususnya pada mail server Universitas Hasanuddin.

\section{KESIMPULAN}

1. Klasifikasi metode bayesian dapat digunakan dengan baik dalam aplikasi email filtering dari serangan spam, pada level client untuk menyaring spam.

2. Semakin banyak jumlah data yang digunakan untuk training pada metode bayesian maka semakin tinggi keakuratannya.

3. Semakin sering dilakukan learning atau penambahan knowledge pada metode bayesian di sisi client maka akan semakin cepat mendapatkan klasifikasi dengan benar.

4. Email filtering dengan metode bayesian masih memiliki akurasi yang tinggi meskipun jumlah data trainingnya sedikit.

5. Pada sisi server, sebaiknya para user meminta langsung pada administrator mail servernya untuk men-setting score dari Spam-Assassin sesuai dengan kebutuhan dari inboxnya.

6. Para user pengguna mail server sebaiknya melatih/ mentraining sendiri emailnya karena hal ini bukanlah kewajiban dari para administrator

\section{SARAN}

1. Di sisi client aplikasi dapat dikembangkan lebih lanjut, misalnya dengan menentukan nilai variasi konstanta bayes secara otomatis untuk mendapatkan akurasi yang tinggi dengan berapapun jumlah data trainingnya.

2. Aplikasi di sisi client dapat dikembangkan lebih lanjut dengan melakukan analisa terhadap body email bertipe html atau mime dan attachment yang dianalisa dari contentnya.

3. Penyaringan spam sebenarnya ada kaitannya dengan admin yang langsung menginstalasi dan mengkonfigurasi web dan mail server yang digunakan, namun bukanlah keharusan/kewajiban tetapi bila tujuannya sekedar menambah kualitas daripada pelayanannya, baguslah kiranya para administrator pada saat menginstalasi dan mengkonfigurasi software yang digunakan, mengaktifkan pengetesan bayes dan jaringan serta auto-learn dari Spam-Assassin sehingga anti spam dapat di update setiap saat dengan menggunakan database jaringannya tergantung kondisi yang dialami para usernya. Tetapi hal ini juga menuntut para user sendiri bisa mengerti dan memahami penggunaannya agar dapat langsung membantu admin dalam mencapai tujuannya.

\section{DAFTAR PUSTAKA}

[1] Alimargono, 2009, Studi Banding, http://alimargono.wordpress.com/2009/01/31/studibanding, diakses tanggal 27 Januari 2014.

[2] Anugroho, P., Winarno, I., Rosyid N. M., 2009, Klasifikasi Email Spam Dengan Metode Naive Bayes Classifier Menggunakan Java Programming, Surabaya.

[3] Fiva, R. 2009, Langkah Mudah Administrasi Jaringan Menggunakan Linux Ubuntu 9. Wahana Komputer, Semarang.

[4] Graham, P. 2002. A Plan for Spam. http://www.paulgraham.com/spam.html.

[5] O’Brien, C., Vogel, C., 2004, Comparing Spam-Assassin with CBDF Email Filtering, Proceedings of the 7th Annual CLUK Research Colloquium, Birmingham, 6-7 Januari 2004. 
[6] Pratama, A. M. R., 2008, Perancangan Dan Implementasi Mail Server Berbasis Qmail Pada Jcpanel Web Hosting Control Panel, Seminar Nasional Aplikasi Teknologi Informasi (SNATI), Yogyakarta, 21 Juni 2008.

[7] Rachli, M., 2007, Email Filtering Menggunakan Naive Bayesian, Tugas Akhir, Jurusan Teknik Elektro Institut Teknologi Bandung, Bandung.

[8] Schwartz, A., 2004, Spam Assassin, O'Reilly Media, Inc., United States of America. 